\title{
大都市圏における構造変化研究の動向と課題
}

—地理学における多核化・郊外の自立化の議論を中心に一

\section{A Review of the Changing Regional Structure of Metropolitan Areas:}

Discussions on Suburban Growth and Multi-nucleation in Geography

\author{
藤井 正
}

\section{Tadashi FUJII}

The suburbanization of various city functions has generated Suburban Downtowns, Edge Cities and Edgeless suburbs in the USA. In Japan, however, the Central Business Districts of major cities still retain comprehensive central functions for the metropolitan area, but large scale shopping centers have also been developed in the suburbs. The regional structures of these two kinds of metropolitan areas, prima facie, seem different. However, we find a common feature present in both types of areas. This involves an interdependent cross-suburb flow structure, which is emerging in many urban areas in the 21st century. The centrality of major cities or CBDs is decreasing. Many of the next suburban generation as well as suburban housewives seldom go to the central city. Similarly, baby boomers, who reside in the suburbs, seldom go after they retire. On the other hand, central cities are now receiving new populations again as a result of the back-to-the-city movement. Are central cities in the process of splitting from suburbs? Or are new overlapping self-contained social spaces emerging all over the metropolitan area? This paper begins with a preface which examines the classic $20^{\text {th }}$ century framework of mono-centric metropolitan areas. Next, there is a review of research mainly in geography related to the multi-nucleation of metropolitan areas. Recently, in sociology, there has been discussion of the need to approach the entire structure of metropolitan areas in addition to examining the rich harvest of research on each suburban community. This paper argues that we need more cross-fertilization of research from these fields in future, that we need to clarify both behavior structures and residential structures in present metropolitan areas, and that the structure of new urban social spaces must also be clarified.

\section{1. 序 論}


間的構造が単核の求心的な構造から変化しつつあるとする研究が, ぞのように展開してき たか，その系譜を整理する ${ }^{11}$ 。そして，転換期を迎える大都市圈やその抱える諸問題への 今後の研究，また新たに展開されつつある都市整備の方向に対しても，この視点から展望 し課題を提示したい。

まず，大都市圏概念について簡単に整理しておきたい [藤井，1990; 富田・藤井， 2001］。大都市圏は，近代都市が爆発的に拡大をはじめ，従来の中心都市だけを都市活 動の空間的範囲として考元られなくなり求められてきた概念である。こうした大都市圈 概念は，3つの意味で使われてきた。ひとつは中心都市から市街地が連続する地域であ り，市街化連担地域と呼ばれる。基本的には土地利用や景観的な面からの定義である。人 口統計としては人口密度などが用いられ，国勢調査の人口集中地区（Densely Inhabited District）もこれに当たる。20 世紀後半になって通勤流動に関するデータが一般に利用で きるようになるまでは，欧米に扔いても都市地域はこうした形で把握されることが多かっ た。2 番目は, 通勤・通学や買い物など日常生活面での空間的まとまりであり, 日常生活 圏として現在一般に利用される枠組みで，これが狭義の大都市圏となっているといえよう。 ニュータウンのような市街地としては中心都市の市街化連担地域から離れ独立したものも, 通勤に代表されるこの第 2 の定義では中心都市に依存し，一体の都市活動を行う現代都市 の空間単位としての大都市圈の一部とみなされる。この日常生活圈は労働力再生産圈とし て経済学的にも都市活動を分析する空間単位としての意義を有し, 都市圈設定の議論が都 市経済学で行われている [徳岡，2006］。3番目は大都市関係圈や影響圈といわれるもの で，中心都市の経済圈や人口転入圈などである。これも広義には大都市圈といわれること もあるが，近代の都市爆発以前からこのような影響圈は当然存在した。そして近代初頭に は市街地連続型のいわゆる都市化以前に, 経済圈内で中心都市の経済活動を中継する周辺 都市から市街地の拡大が展開したと考元られ,「中継的都市化」として考察されている[青 木，1986]。20世紀の中頃までのオリジナルな意味での田園都市や衛星都市は，この経 済圈の内部で日常生活圈の外にあたる位置に構想されたのである [藤井, 1981]。

現代の日本の大都市圈を主に扱う本稿においては, 基本的には大都市圈の地域構造を次 の枠組みで考える。中心都市とは第 2 次大戦後における居住機能や工業・物流機能の爆発 的な郊外化が扔こる以前の中心都市市街地の範囲であり, 日本では多く都市で城下町の歴 史を持つ都心とその周辺に近代に入って工業化で拡大したインナーシティ的性格を持つ 旧市街地からなる。この中心都市の空間的把握に際しては，便宜的に中心市域を用いる ことが多い。大都市圈内でこの中心都市の外側の領域をここでは郊外と呼ぶ。準都市的 という sub・urb の原義通り, 日常の生活行動において中心都市に強く依存し一体化した 空間であり, したがって現代の都市活動の空間的まとまりは, 強い求心的な構造を持つ 大都市圈（日常生活圈）を単位としてきた。この大都市圈の範囲設定については，成田 [1995］に拈いて詳細な検討が㧍こなわれている。最近では都市経済学からの近年の都市 
圈構造の変化もふまえた都市圈設定の再検討を徳岡が整理しており，その都市圈設定にも とづく都市化から再都市化に至る後述の発展段階説の再検討も山神によって行われてい る [徳岡，2006；山神，2003］。なお，この大都市圈の全体的な空間構造をめぐる議論 では，アメリカ合衆国で指摘された超郊外 (exurb) という領域も問題となる。これについ ては，この大都市圈の外側（近接地）でありながら都市化が進む領域と考えられ，反都市 化 (counter-urbanization) あるいは逆都市化（des-urbanisation）として指摘された大都 市圈外の人口増加地区のうち大都市圈に近接した地区をさすと考元られる [藤井，1990］。 次に地理学における地域概念について，本稿における意味を中心に簡単に説明しておき たい。都市社会学でも, 早くから以下の整理とも一部共通する興味深い空間概念の整理が 行われており [町村, 1986], 最近では地域概念をめぐって, 都市化がコミュニティとし ての「地域」の意義を低下させる一方で，その現代的な必要性も議論されている[西澤, $2000 \mathrm{a} \cdot \mathrm{b}]$ 。ところで地理学における地域は，コミュニティ以外の多様な要素も含む空間 的なまとまりである。地理学の最近の議論 [Blotevogel, 1996; 森川, 1997]では, 従 来の地域概念の定義である，地形や土地利用，社会地区のまとまり（これらを等質地域と いう), あるいは通勤や経済関係などの結合関係の空間的なまとまり（結節地域・機能地 域 2)）としての客観的な地域（これら 3 地域をまとめて「実質地域」と呼ぶ）に加え, 次 の二つの地域概念が整理されている。ひとつは自宅や職場というアンカーを中心に生活行 動が生み出すメンタルマップ的な地域 [岡本，2000］にアイデンティティや地域観をも 含め, 空間的イメージにみられる個人や社会集団の主観的な構造的まとまりを「認知地域」 として把握するものである。さらに社会が空間（地域という空間的構造のまとまり）をつ くる側面（たとえば都市計画や市場開拓）に関して「活動地域」も提起されている。この 「活動地域」における空間的まとまりは, まだ組織化途上のものである点で最初の既存構 造を対象とする「実質地域」とは異なる。なお, ここでの地域は, 空間スケールという点 ではさまざまな大きさを持つ。またこれら 3 地域概念は, 後述のように社会が地域構造を つくり地域構造が社会的行為を規定するという社会と空間の相互規定関係に迫ろうという 枠組みでもある。

\section{2. 構造変化研究の系譜}

a．都市の発展段階説と反都市化研究

大都市圈の地域構造が, 単核・求心的なものから多核的なものに変化しつつあるので はないかという構造変化研究の発端は, 1970 年代のアメリカ合衆国において, 大都市圈 人口の増加を非大都市圈人口の増加が上回ったことにあった。日本でも人口Uターンや 地方の時代が説かれたのと同時期に, 先進国に共通する人口動向をめぐって, 反都市化 (Counter-urbanization) や逆都市化 (des-urbanisation) と呼ばれたこの現象の議論が地 
理学や都市経済学, 人口学などで展開したのである [大阪市立大学経済研究所, 1986； 富田, 1995 ; 石川, 2001 ; 山神, 2003]。都市経済学の分野では, クラッセンらがこ れを逆都市化と呼び, 都市化, 郊外化, 逆都市化, 再都市化という発展段階説を展開し た。現在でもいわゆる人口の都心回帰などをめぐって使われる逆都市化という言葉のルー ツはここにある [松本，2004]。なお，この場合の再都市化とは，逆（反）都市化すなわ ち大都市圏全体の人口停滞・減少（人口ドーナツ化による中心都市の相対的衰退ではな い）の後に来る再成長期を指し，世界都市化との関連で論じられたこともあった［成田， 1995]。最近の地理学の研究では山神 [2003］が，いわゆる都心回帰の位置づけなども含 めてこれら都市発展モデル群の検討を行っている。

また, 反 (逆) 都市化（大都市圈全体の人口減少）の研究については, 全国スケールで の人口移動研究において国際比較としても展開する。石川 [2001］がこれらの研究を総 括し，大都市圏をめぐる人口Uターンや反（逆）都市化，そして再都市化や人口回㷌と呼 ばれるこういった動向は先進国共通のもので, ベビーブーマーのライフサイクルや景気の 循環的変動，世界都市化など多様な要因が考えられると結論づけている。

b . 大都市圏の多核化と郊外の自立化

一方，藤井 [1990］では，こうした反（逆）都市化は大都市圏の空間構造の問題であ ることを主張した。すなわち，反都市化では大都市圈よりも非大都市圈での人口増加率が 大きくなる。たしかに非大都市圈でも大都市から遠く離れた地方都市や農山村での人口増 加は，まさしく全国スケールの人口移動の転換といえよう。だが，大都市圏のすぐ外側， 上記の超郊外 (exurb) での人口増加をどのように考えるかが問題となるのである。この超 郊外での人口増加のメカニズムは次のように考えられる。郊外化は，人口に続いて就業機 能でも展開する。その結果, 郊外での就業者が増加し, それら郊外への通勤者が中心都市 通勤者の居住地（郊外）のさらに外側に居住していった場合，都市地域は拡大するが，中 心都市への通勤圏すなわち大都市圈とはみなされないこととなる。つまり，この超郊外の 問題は，全国的な人口移動の問題ではなく大都市圏の構造変化の問題なのである。

こうした問題意識もあり, 大都市圈の構造変化に関する地理学研究においては, 経済活 動の郊外化や業務中心の多核化の研究が展開した。人口の郊外化に続き, 工業や流通機能 が，そして最後にオフィスが郊外化して郊外が自立し大都市圈は完全に多核化するという 考え方である。たとえば，郊外のホワイトカラー従業率からその自立化を検討する［成 田，1995］など，この枠組みと先の発展段階説を基礎として，多くの実態の分析や検証 が重ねられた [富田, 1995 ; Jenkens, 1996 ; 石川, 1996・1997；古賀，1998］。しかし， 大都市圏は，上述のように日常生活圈として本来定義されており，その構造変化を経済的 な中枢機能の立地だけから論じるのは問題がある。通勤や買い物など生活行動面からも分 析が求められる [藤井, 1990]。こうした生活行動の広がりについて, 時間地理学的な研 
究を展開したのが後で詳述する川口［1994］である。また佐藤・荒井［2003］は，オフ イスの郊外化の結果, 就業者の生活行動がどのように変化するのかを東京を事例に分析し, 錯綜した通勤流動が生じ，必ずしも通勤距離の短縮を招かないことを示した。

この機能立地と生活行動の問題は, 郊外の自立化に関する議論 [Muller and Hartshorn, 1989]，すなわちアメリカ大都市圈に関する郊外都心（Suburban Downtown）や郊外都 心を中心とした領域が中心都市依存から独立するという Urban Realmsをめぐる議論と 深く関連する。これはジャーナリストである Garreau [1991] の Edge City 論が時期を 同じくして地理学的に展開したものであった。しかしこれらの郊外領域群の完結性には生 活行動面や機能面から首肯できないことが明らかにされる [Fujii and Hartshorn, 1995]。 実際には，領域にまたがる錯綜した生活行動が展開し，機能的にもそれぞれの郊外都心が フルセットの機能を持つのではなく，多核的な都市地域全体（大都市圈）で機能的にもま とまっているというべきである。

このような生活行動の展開については，日本では川口［1994］が郊外の時間地理学的 な分析により次のような整理を提示した。都市機能の郊外化やモータリゼーションの展開 とともに, 自宅周辺の近隣圏と大都市圏にあたる都心圈との中間スケールにあたる郊外 圈という生活空間の形成が近年進展をみた。これが大都市圈多核化の生活行動面からの メカニズムであるとする。また, 居住地移動と通勤流動との関係の研究 [谷, 2002 ; 稲 垣，2005］からは, 郊外若年層の就業構造がひとつの焦点として浮上している。英語圈 に抢ける大都市圈の多核化とUrban Realms の関係についても, 都心の弱いアメリカの アトランタなどや逆に日本の大都市圈のように都心機能を維持しつつ多様な機能の郊外化 がすすむオーストラリアのメルボルン大都市圈, カナダの都市での分析例など事例研究 が重ねられてきた [Fujii and Hartshorn, 1995; Kling, et.al, 1995; Forstall and Greene, 1997; Healy and O’Connor, 2001 ; Shearmur and Coeffery, 2002 ; Sultana, 2002 ; 藤 井, 2004 ; Hartshorn, 2005; Fujii et.al, 2006; Yamashita et.al, 2006]。それらの研究 からも，錯綜した生活行動の展開が多核化の一般的な要因として明らかになっている。ア メリカでは都心の内部構造に関しても, アトランタやロサンゼルスの研究などで示される ように, いわば郊外と同様の形態へと拡散化・低密化も進んでいると考学られる [Forstall and Greene, 1997; 藤井, 1999]。そしてこれもまた, 錯綜した流動の一般化をもたらす ものなのである。

\section{c. Edgeless な郊外化}

このように多核化（構造変化）研究では, 単核の求心的な大都市圈から, 都市機能が順 次郊外化し郊外で集積することにより，多核的な郊外都心を中心に新たに郊外の各領域 が自立化し，大都市圈からいわば独立するという展開が想定されてきた。しかしながら 一方で，拙稿 [1990］では，このような集積による多核化とは別に，上記の錯綜した流 
動が生み出す分散的な多核化が，郊外核集積への過渡的なものに限らない，単核求心構 造を崩す，大都市圏の構造変化の本質の一翼をなすものであることも主張した。アトラ ンタのように郊外核が都心クラスになり多核化した大都市圏でも，都心が強い求心力を 持つ日本やオーストラリアの大都市圏でも，このような流動は展開していた [Fujii and Hartshorn,1995; Fujii et.al, 2006]。また, 1990 年代初めの郊外都心形成以降のアメリ カ大都市圏では，郊外核の集積を見ない Edgeless と呼ばれる郊外化の展開がひとつの論 点となった [Lang, 2003; Hartshorn, 2005]。こうした郊外化の状況に着目した多核化論 への反論などは，分散化論やポストサバーブ論などとしても取り上げられている [Kling et.al, 1995; Gorden and Richardson, 1996；水上, 2002]。このように構造変化論の本 質は，錯綜した郊外間流動，生活行動の展開にあると考えられる。この点については，最 後に詳述したい。なお，地理学や社会学以外でも経済学などの分野でこうした一連の多核 化や郊外の自立化をめぐる研究が，基本的な大都市圈の構造変化を明らかにするものとし て評価されている [阿部, 2004 ; 徳岡, 2006]。

\section{3. 最近の大都市圏の動向や整備に関する研究}

最近の大都市圏をめぐっては，人口の「都心回帰」や郊外住宅地の衰退問題など，あら たな動向や問題が取り上げられている。それでは大都市圈の構造変化に関するこれまでの 研究視点からは，こうした最新の問題はごのように位置づけられるのであろうか。

まず，東京の動向をめぐっては，矢部の早い時期の事例研究や全国的な人口移動の動向 分析をも含めた江崎の詳細な論考が公刊されている [矢部, 2003 ; 江崎, 2006]。大阪 に関しては富田の都心と郊外マンションの人口移動などをめぐる比較研究がある [富田, 2005 ・2007]。また，郊外居住者（兵庫県三田市）の将来の居住志向は，大都市「回帰」 は少なく，阪神間などが比較的多い [藤井・山中，2005]。これらの研究から示されるの は，ドラスティックな郊外への移動がおさまり，ドラスティックな都心回帰が起こるので はなく，画一的な郊外への移動から多様化へという大きな動向の転換で，多様な居住志向 が実現可能となったこと，そのような志向に答えうる個々の場所の評価が問題となってい ることが示されている。土地評価についても，大都市圈全体の統一的な相場的な評価でな く，個々の場所の文脈による評価に転換しつつあることが山田 [2007］によって示され ている。これは経済格差の拡大と対応するものとも考えられており, 後述の東京都市圈の 中心部にみられる比較的高所得のホワイトカラーの厚い集積と周辺部の社会地区構成との 関連性ともあわせて, 今後さらに検討の必要がある。都心回帰のこのような評価について は，成田の論考が参考となる。先進国大都市での反都市化，そして世界都市化とグローバ リゼーションによる少数都市の再都市化について, 成田 [1995：18］は郊外化から都心 回帰へといった一様な居住動向の転換としてではなく, 多様なライフスタイルの選択可能 
性を示すものとする。そこではまた，後でも論じる中心都市と郊外の共生［成田，2005］ や日本全体の人口減少による都市の縮小，郊外住宅地の選別，その計画的対応策の構築が 問題となる ${ }^{3)}$ 。

最近の都市計画や都市政策において，環境問題に対応し，人口減少下においても暮らし やすい町をつくり，効率的な公共サービスが得られるために注目されている考方方とし て，コンパクト・シティ (Smart Growth) 政策がある [海道，2001；藤井，2007］。実は， コンパクト・シティといっても，都市圈にひとつのコンパクトなまちをつくるのではなく， コンバクト・タウン群から都市圈を構成すべきであるという考元方もある。そこでは多核 的な都市圈構造が当然深く関連することとなる。しかし，都市計画などのこれまでの研究 では，各都市核間の機能配置や機能分担，あるいは社会構成の問題は，ほとんど検討され ていない。上記の多核的な郊外領域間の関係や中心都市と郊外の共生の問題などをはじめ, 多核的な地域整備の課題に論究していくためにも，大都市圈全体の社会構造に関する研究 を蓄積していく必要がある。

\section{4. 社会学研究との交点}

社会学の郊外研究からは，地理学研究の動向も視野に入れた展望論文が示されている [高木，2000・2006 ; 三隅，2001］。そこでは大都市圈の全体構造の考察が必要であるこ とが論点のひとつとなっている。社会地図とその手法を用いた研究 [倉沢・浅川，2004； 浅川，2006］やコミュティの類型化の研究 [和田，2006］は，そういった方向での研究 展開であろう。これについては，上で論じた大都市圈形成と多核化のメカニズムに関する 議論やこれまでの地理学を中心とする多くの研究が，社会地区構成を主として扱った研究 ではないとはいえ参考になろう。本特集でも特に関連深い谷の居住経歷や制度論的な側面 からの空間的構造の考察, 豊田の地価・所得など経済的な側面からの空間的構造の考察が 展開されている。

また，大都市圈の社会と地域（空間）をめぐっては，最初にあげた地理学における Blotevogel による 3 地域概念（実質地域・認知地域・活動地域）がフレームワークとし て重要なものとなると考元られる。空間と社会の関係をプロセスとして整理し得るこの地 域概念と類似の整理枠組として, 若林は「社会の地形」というフレームワークを提示して いる [若林，2000; 若林，2001，p.41］。そしてそこから「郊外の社会学」の確立を説 くが [若林，2001，pp.40-41］，現在の郊外は若林も論述するように 20 世紀の大都市圈 全体の社会プロセスの中で形成されてきたものである。そして, 現在大都市圈の全体構造 の変化する中で，上述のような多数の研究者がそれを解明すべくアプローチしているよう に，その姿をいままさに変えようとしていると思われる。したがって，郊外の社会学は， 「『郊外』という場がどのように現れれてきたのか」(若林，2001)，郊外を生み出してきた 
「構造的文脈」(三隅，2001）とともに，大都市圏の構造変化の中で今後どのような姿が想 定されるのかというテーマにも目を向けていく必要があろう。

一方, 大都市圏の全体構造を居住分化から分析した論文として, 社会学では倉沢・浅川 や牛島, 浅川の研究があり [牛島, 2001 ; 倉沢・浅川, 2004 ; 浅川, 2006], 地理学と の共同研究の成果として熊谷・矢部 [2006], 熊谷 [2006] などがあげられる。牛島は, 郊外の年齢構成別の家族分布などを詳細に分析し, 若年齢層の郊外吸収を雇用機会の郊外 化などから説明している。これは先の郊外の自立化につながる議論であり，地理学におけ る谷 [2002］や稲垣 [2005］による若年就業の分析とも通底する。江崎は首都圈のセク ター別分析から, 大学立地による若年層流入の弱い北東セクターの高齢化を予測する [江 崎, 2006]。また，そこで触れられている郊外住宅地・ニュータウンの高齢化のフィジカ ルな問題や継承性については, 地理学でも江崎の研究の他に坪本 [2007] の研究などが あり，またコーホートとの関連から川口［2007］の考察が行われている。これは，人口 減少時代に入って, 都市の縮小が論じられ, コンパクト・シティの整備が課題となってい ることとも深く関連する。今後は, こうした地理学と社会学における研究の意見交換や交 流が求められよう。

このように現在, 郊外に関して, 戦前の高級郊外住宅開発, 戦後の大衆的郊外化の時代 に次ぐ，第 3 の画期を迎えているのではないかと考えられ (本号の谷論文)。社会的な分 極化と関わる変化（たとえば本号の豊田論文）や少子高齢化の中での生活空間の変化 [坪 本・樋口, 2005] はその一局面と位置づけられる。そして大都市圈の空間（地域）構造は, 上で論じたように, 求心的な階層構造から相互依存的な重層構造として理解すべきものへ と変化していると考えられる。まさに, 地域／場所（大都市圈や Realmなど）とは境界 が不明確でネットワーク的なプロセス [Massey, 1994；水野, 2003]として理解して ゆく必要がある。

\section{5. 結 論}

最後に序説と前章で言及した地域概念との関係で, この大都市圈の構造変化すなわち多 核化や郊外の自立化の議論を整理しておきたい。先にも論及したように都市社会学では都 市化（大都市圏形成）が地域コミュニティとしての「地域」意味を減退させ，一方現代 的なその必要性も説かれている [西澤, 2000a]。この際の大都市圈形成を地理学的に説 明したのが本特集で谷が論じる社会的・空間的プロセスである。序説の 3 地域概念の枠 組みに位置づけると, 近代都市社会が自治体の都市計画 ${ }^{4)}$ や電鉄会社の沿線開発 [水内, 2001]として認知地域であるビジョンを背景に活動地域として事業展開をはかり, 市街 化連担地域や通勤圏としての, つまり実質地域の大都市圈が形成されることとなる。そし てこのフィジカルな地域構造に規定された生活行動の展開の中で, 郊外の自宅と都心にア 
ンカーを持つ認知地域であるメンタルマップが形成される [藤井, 2001]。一方, 都市機 能の郊外化とともに上述のように大都市圈の多核化や郊外の自立化が議論される。都市政 策面で今主張されているコンパクト・シティ（新たなビジョン）も，大都市圏形成の結果 としての経済効率という点ではすぐれた地域構造から, あらたな価值観による大都市圏の 地域構造への転回が必要とされ，整備事業が進もうとしていると考えることができよう。

このような転換期の大都市圏をめぐる重要な研究課題として次の点があげられる。モビ リティの高い現代都市における地域構造は，かつてのような階層的な空間単位の重なり （結節地域）という形だけでは整理できず，もっと錯綜した結合関係のまとまり（機能地 域) [藤井，1990]，アレグザンダーのいうセミラティス構造として理解しなければならな い [藤井, 1993 ; アレクザンダー, 1984]。こうした錯綜した郊外間結合の展開は, 中 心都市（都心）が高い中心性を持つ日本の大都市圈やオーストラリアのメルボルンにおい ても，中心都市が弱体化し多核化した典型のアメリカのロサンゼルスやアトランタでも 同様に展開している [Fujii and Hartshorn, 1995; Kling et.al., 1995; 水上, 2002 ; 藤 井・山中, 2005; Fujii et.al., 2006]。その結果として，郊外核へ通勤などで結合する住 民が，従来の大都市通勤圈の外に居住するようになる。これが大都市圈の構造論での超郊 外 (exurb)であり,大都市地域としては中心都市通勤圈をこえてさらに拡大が可能となる5 これは機能的・経済的には, 中心都市依存から郊外への機能立地により生活行動が多様化 した結果であり，ミクロには社会学研究が説くように [西澤, 2000b ; 和田, 2006], 均 質な郊外社会構造の変化により社会的なネットワークが地域コミュニティをべースに多層 化していくことによるものと考朰れる。

そしてこれは，インナーシティ研究 [成田，1987］が機能分化した近代都市空間に対 して, むしろ混在に再評価を与えたように, またジェントリフィケーション研究で単に新 住民の流入でなくその場所でどのような社会関係が生み出されるかを問題とすべきとされ るように [Atkinson, 2005], 住宅地の継承が問われる郊外でも, 新たな集合住宅群が建 設された都心でも同様に問題となる構造である。職住分離, 機能分化, 人口ドーナツ化に よる都心・インナーシティ・郊外という大都市圈構造の形成から, 錯綜した生活行動が重 層的に展開する構造へ, 単核の求心性を低下させた大都市地域の社会空間構成は姿を変 え，それを構成する各地域の多面的な自立性がこれからは問われようとしている6。一方 で, 浅川が居住地ベースの社会地区分析から指摘した, 東京大都市圈に抢ける 90 年代に おける同心円構造の強化 [浅川，2006］との関係についても解积が必要となる。先の錯 綜する流動は, 機能立地にともなう社会的ネットワークに関するもので, 居住地の社会地 区として示されるセクター構造が衰退し同心円構造が強化されているという指摘との関連 は，次のように考元られる。つまり，上述の川口［1994］が明らかにした近隣圈や都市 圈とは異なる郊外圈という生活空間の成長に見られるょうに, 社会的ネットワークが既存 の伝統的コミュニティやブルーワーカーのセクターで近隣圈に拀いて収斂したり, 郊外に 
おける都心圏の強さが，90 年頃までの構造においてはまだみられた。それが近年は，大 都市地域全体にわたってこれらの中間スケールで錯綜して展開をはじめているとはいえな いだろうか。この議論の展開には, 浅川 [2004] のような社会地区と関連づけた生活圏 研究との意見交換や生活圈の変化に関する研究の展開が求められる。

また大都市圈の比較を進めるに際しても, このような大都市圈構造をめぐる視角は重要 なものとなる。大阪大都市圈では, 東京大都市圏よりも中心都市部の厚いホワイトカラー 層による同心円構造は弱いと思われる [木村他, 2002 ; 熊谷・矢部, 2006］。この点に 関して，両都市の評価はどのようなものになるのであろうか。大阪はサービス経済化にお いて遅れをとった大都市ということになるのか, 都心アクセスという選択肢を広く多様な 社会地区（社会集団）に与えうる都市と考えられるのであろうか。また，大阪でも錯綜す る生活行動は東京と同様に展開している。この中心都市の若く単身率の高いホワイトカラ 一集積は，上でも述べたように，郊外圏に相当する中間圈を構成すると考えられる。しか し, 成田 [2005] の説く中心都市と郊外が共生し社会的に融合した住み分け可能な大都 市地域をつくるには, 今後の日本社会を考える上で世代や所得, ライフスタイルの点で, この社会地区の特化あるいは固定化は，慎重に分析・評価する必要があろう。多核化研究 において郊外間流動として見いだされ，大都市圏の構造変化をの本質となる，錯綜する生 活行動をめぐって，地理学ならびに社会学において検討すべき課題は多いといえよう。

[付記］本研究には，平成 $16 \sim 18$ 年度科学研究費補助金・基盤 $\mathrm{A}$ （課題番号 16202022）「社会 経済構造の転換と 21 世紀の都市圏ビジョン一 欧米のコンパクト・シティ政策と日本の都市圈構 造 一」(代表：藤井 正）ならびに平成 $18 \sim 20$ 年度科学研究費補助金（基盤研究 (C)）「我が国に おけるリバブル・シティ形成のための市街地再整備に関する地理学的研究」(研究代表者 : 山下博 樹）の一部を使用した。

\section{注}

1) 都市化研究から都市圈研究へといった都市地理学研究における大きな流れについては, 阿部が 鋭い整理を展開している（阿部，2003）。

2) 結節地域と機能地域の相違については, 藤井 [1990] 参照。

3）たとえば，䇾原 [2003]。

4) 関一を中心として大阪市は, 1919 年の都市計画法成立後, 郊外と一体となった大都市圈, 郊 外からの通勤という新しい都市空間のビジョンの下, 周辺部を含めた「大大阪」の都市計画を制 定し都市計画事業として都心（御堂筋や大阪駅前整備）と郊外（周辺町村の合併と土地区画整理 事業の展開）の両者の整備を展開する [藤井, 2006]。

5) なお, すでにこのような構造変化については都市圈の定義においても議論され設定の修正が行 われている [徳岡, 2006]。

6) ノックスとピンチは, 社会空間的分化の近年の状況について,「都市空間の断片化?」として, 「細分化された構造の出現」と考える一方，上記の多核化分析が明らかにしたように都心と郊外の 
差異が消滅し，郊外空間が一般的な構造になりつつあるとする [Knox, P. and Pinch, S., 2000, p.117, 訳書, p.96]。

文献リスト

阿部和俊, 2003, 『20 世紀の都市地理学』古今書院.

阿部真也, 2004, 「大都市圈における小売業の分散化と消費者」, 白石善章 - 田中道雄編『現代日本 の流通と社会』ミネルヴァ書房.

青木伸好, 1986, 『地域の概念』大明堂.

アレクザンダー，C，1984，「都市はツリーではない」(押野見邦英訳，原著初出は 1965 年）前田 愛編『テクストとしての都市』別冊国文学 22 号, 25-46.

浅川達人, 2004, 「生活圏の編成」, 倉沢進 - 浅川達人編, 『東京圈の社会地図 1975-90』東京大学 出版会.

一, 2006, 「東京圈の構造変容一変化の方向とその論理一」曰日本都市社会学会年報』24, 57-71.

Atkinson, R., 2005, "Gentrification and Urban Policy in the UK: Safety and the Return of High income Groups to Inner city Living”, 人文地理学会都市圏研究部会要旨, 『人文地理』54-3, 96.

Blotevogel, H.H., 1996, “Auf dem Wege zu einer 'Theorie der Regionaltät': Die Region als Forschungsobject der Geographie”, Brunn, G. (Hrsg.) Region und Regionsbildung in Europa.

Konzeptionen der Forschung und empirische Befunde. Baden-Baden: Nomos=Schriftenreihe d. Inst. f. Europ. Regionalforschungen 1, 44-68.

江崎雄治, 2006, 『首都圈人口の将来像一都心と郊外の人口地理学一』専修大学出版局.

Forstall, R. L. and Greene, R. P., 1997, “Defining job concentrations: the Los Angels case”, Urban Geography, 18-8.

藤井 正, 1981, 「京阪神大都市圈と衛星都市一大都市圈研究における衛星都市再考の試み一」人 文地理』33-1, 62-77.

， 1990，「大都市圈における地域構造研究の展望」『人文地理』42-6, 40-62.

一，1993，「最近の都市への視点について一地域の文脈の解明と主張に向けて一」大阪府立 大学紀要 (人文・社会科学) 41, 25-33.

—, 1999 ,「アトランタ大都市圏の多核化とオフィス立地」成田孝三編『大都市圈研究 (下)』 大明堂, 121-142.

—，2000，「新旧都市空間の形成と変化 一アトランタ大都市圈の多核化を事例に一」足利健 亮先生追悼論文集編纂委員会編『地図と歴史空間』大明堂，490-501.

— , 2001,「メンタルマップに見る大阪圈の構造変化」, 富田和暁・藤井正編, 『図説 大都市圈』, 古今書院.

——, 2004,「都市圈に関するこれからの地理学的研究の意義と課題」人文地理学会特別研究 発表要旨 http://www.jstage.jst.go.jp/article/hgeog/2004/0/2004_2/_article/-char/ja/

—, 2006, 「京阪神大都市圏」「都市的土地利用の拡散と都市計画」金田章裕・石川義孝編『日 本の地誌 8 近畿圈』朝倉書店.

，2007，『社会経済構造の転換と 21 世紀の都市圈ビジョン一欧米のコンパクト・シテイ政策 と日本の都市圈構造一』平成 $16 \sim 18$ 年度科学研究費補助金基盤 $\mathrm{A}$ （課題番号 16202022） 研究成果報告書. 
Fujii, T. and T. A. Hartshorn, 1995, "The Changing Metropolitan Structure of Atlanta, Georgia: Locations of Functions and Regional Structure in a Multinucleated Urban Area", Urban Geography 16, 680-707.

藤井 正・山中拓真，2005，「郊外ニュータウン地区住民の社会特性・居住動向と生活行動一兵庫県 三田市におけるアンケート調査結果の概要一」『市史研究さんだ』8, 43-68.

Fujii, T., Yamashita, H., and Itoh, S., 2006, “A Comparative Study of Metropolitan Multi-nucleation: Suburban Centres and Commuter Flows within the Metropolitan Areas of Atlanta, USA, and Melbourne, Australia”, Applied GIS 2(2). 11.1-11.17, DOI:10.2104/ag060011.

Garreau, J., 1991, Edige City: Life on the New Frontier, Anchor Books.

Gorden, P. and H. W. Richardson, 1996, "Beyond Polycetricity: The Dispersed Metropolis, Los Angels, 1970-1990”, Journal of the American Planning Association, 62, 289-295.

Hartshorn, T. A. and P. O. Muller, 1989, "Suburban Downtowns and the Transformation of Metropolitan Atlanta's Business Landscape”, Urban Geography 10, 375-395.

Hartshorn, T. A., 2005, "Is there a North American City? : A Review of Recent Evidence”, in Cities in Global Perspective: Diversity and Transition (Proceedings of the Tokyo Conference in Aug. 2005 by Urban Commission on Monitoring cities of tomorrow, International Geographical Union), edited by Yuji Murayama and Guoquing Du, College of Tourism, Rikkyo University with IGU Urban commission, Tokyo, Japan, 11-17.

Healy, E. and O'Connor, K, 2001, “Jobs and Housing Location in Melbourne, 1986-1996: New Insights on Metropolitan Developent”, Australian Planner 38-1, 9-15.

稲垣 綾, 2005 , 「大都市圈郊外に立地する事業所のアルバイト求人行動と若年者の求職行動」『人 文地理』57-1, 25-46.

石川義孝編著, 2001, 『人口移動転換の研究』京都大学学術出版会.

石川雄一，1996，「京阪神大都市圈における多核化の動向と郊外核の特性」『地理学評論』69-6, 387-414.

一，1997，「大都市圏における多核化の展開と通勤流動パターンの変化一京阪神大都市圏に おける 1980 - 90 年の動向一」『経済研究所年報』(金沢経済大学) 17，23-47.

Jenkens, L., 1996, Office Location in a Post-Industrial Urban Environment, Avebury.

海道清信, 2001, 『コンパクトシティ』学芸出版社.

川口太郎，1994，「東京大都市圈の地域構造変化と郊外の生活空間」高橋伸夫・谷内達編『日本の 三大都市圈』古今書院.

—，2007，「人口減少時代における郊外住宅の持続可能性』駿台史学』130, 85-113.

，2007，「社会経済的人口属性からみた大都市圈空間構造の変遷」『明治大学人文科学研究 所紀要』 60, 53-76.

木村義成・富田和暁・藤井 正，2002，「ジオデモグラフィクスからみた東京・京阪神大都市圈の居 住地域構造」人文地理学会都市圈研究部会要旨, 『人文地理』54-3，108-110. 図を含む要旨 は次のサイト, http://www.ed.kanazawa-u.ac.jp/ urban/20020309.html.

Kling, R., Olin, S. and Poster, M., 1995, Postsuburban California: The Transformation of Orange County since World War II, University of California Press.

Knox, P. and Pinch, S., 2000, Urban Social Geography: Introduction, Fourth Edition, Pretince Hall, 2005. 川口太郎・神谷浩夫・高野誠二 訳, 2005, 『新版 都市社会地理学』古今書院.

古賀慎二，1998，「オフィスの立地からみた三大都市圈の構造変容 一事業所の形態からのアプロー 
チ一」立命館文学』553.

熊谷美香, 2006, 「社会地図でみる大都市圈構造と比較研究のアプローチ」『市政研究』150, 108-117.

熊谷美香・矢部拓也，2006，「GIS を用いた大都市圈の比較研究一東京圈と京阪神圈の社会空間構 造比較一」『徳島大学社会科学研究』19, 251-262.

倉沢進・浅川達人編, 2004, 『東京圈の社会地図 1975-90』東京大学出版会.

Lang, R. E., 2003, Edgeless Cities: Exploring the Elusive Metropolis, Brookings Institution Press.

Massey, D., 1994, “A Global sense of place”, in Massey, D., Space, Place, and Gender, Cambridge, Polity Press, 146-156.

町村敬志，1986, 「都市社会と都市空間の関係性」吉原直樹・岩崎信彦『都市論のフロンティア』 有斐閣選書, 73-77.

町村敬志・西沢晃彦，2000，『都市の社会学一社会がかたちをあらわすとき一』有斐閣。

松本 康編著, 2004『東京で暮らす一都市社会構造と社会意識』東京都立大学出版会.

䇾原＼cjkstart敬，2003，『成熟のための都市再生 一人口減少時代のまちづくり一』学芸出版社.

三隅一人，2001，「都市社会学的『郊外』研究のために」日本社会学会年報 $19 『$ 郊外論のゆくえ』, 3-21.

水上徹男， 2002，「ポストサバーブと都市論の新たなアプローチ」都市問題』93-5，25-34.

水野真彦, 2003,「地域政策における『地域』とは何か？一英米の地域政策をめぐる議論から一」人 間科学論集』(大阪府立大学総合科学部) $32 \cdot 33,1-19$.

水内俊雄, 2001 , 「戦前期の大阪における郊外社会 - 郊外生活」富田和曉・藤井正『図説 大都市圏』 古今書院.

森川 洋, 1997, 「ドイツにおける地誌学の研究動向」『地誌研年報』 6 .

成田孝三，1987，『大都市衰退地区の再生』大明堂.

一，1995，『転換期の都市と都市圈』地人書房.

一，2005，『成熟都市の活性化』ミネルヴァ書房.

西澤晃彦，2000a，「居住点から拡がる社会」町村敬志・西澤晃彦『都市の社会学』有斐閣，

$175-201$.

一，2000b，「郊外という迷宮」町村敬志・西澤晃彦『都市の社会学』有斐閣，203-234.

大阪市立大学経済研究所 田口芳明・成田孝三編，1986, 『都市圈多核化の展開』東京大学出版会.

岡本耕平, 2000, 『都市空間における認知と行動』古今書院.

佐藤英人・荒井良雄, 2003 ,「オフィスの郊外立地に伴う就業者の住居選択 一大宮, 幕張, 横浜を 事例として一』地理学評論』76-6.

Shearmur, R. and W. Coffery, 2002, "A Tale of Four Cities: Intrametropolitan Employment Distribution in Toronto, Montreal, Vancouver, and Ottawa-Hullm1981-1996”, Environmental and Planning A, $34,575-598$.

Sultana, S, 2002, "Job/Housing Imbalance and Commuting Time in the Atlanta Metropolitan Area", Urban Geography 23, pp.728-749.

高木恒一, 2000, 「都市社会学における郊外研究の課題」『愛国学園大学人間文化研究紀要』2, 91-105.

一, 2006, 「都市社会学における地理的概念」人文地理学会都市圈研究部会（GIS がつなぐ 都市社会学々都市地理学) 要旨, 『人文地理』58-5, 92.

高橋伸夫・谷内 達, 1994, 『日本の三大都市圈』古今書院. 
谷 謙二, 1997,「大都市圈郊外住民の居住経歷に関する分析 一高蔵寺ニュータウン戸建住宅居住 者の事例一」『文地理』50, 263-286.

，2002，「1990 年代の東京大都市圏における通勤流動の変化に関するコーホート分析」『地 理学研究報告』(埼玉大学教育学部) $22,1-21$.

—, 2004, 「戦時期から復興期にかけての東京の通勤圈の拡大に関する制度論的考察」『地理 学研究報告』(埼玉大学教育学部) $24,1-26$.

徳岡一幸，2006，「都市経済と都市圏』都市研究』(近畿都市学会） 5 ・6 , 15-27.

富田和暁, 1995, 『大都市圈の構造的変容』古今書院.

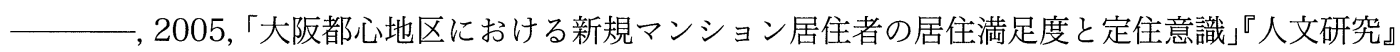
(大阪市立大学大学院文学研究科) $56,65-89$.

，2007，「大阪府北部地域における新規マンション居住者の居住満足度と定住意識」藤井 正『社会経済構造の転換と 21 世紀の都市圈ビジョン一欧米のコンパクト・シティ政策と日本 の都市圈構造一』平成 $16 \sim 18$ 年度科学研究費補助金基盤 $\mathrm{A}$ （課題番号 16202022）研究成 果報告書, 5-13.

富田和暁・藤井 正編, 2001, 『図説 大都市圏』, 古今書院.

豊田哲也，1999，「社会階層分極化論と都市の空間構造一束京特別区の事例一」成田孝三編『大都 市圈研究 (上)』大明堂.

坪本裕之・樋口民夫，2005，「地形図で考える高齢者の日常生活と地域交通」宮澤仁清編『地域と 福祉の分析法』古今書院.

坪本裕之, 2007, 「変容する大都市郊外住宅地における住環境保全と『高齢者』の発現」藤井正『社 会経済構造の転換と 21 世紀の都市圏ビジョン一欧米のコンパクト・シティ政策と日本の都市 圈構造一』平成 $16 \sim 18$ 年度科学研究費補助金基盤 $\mathrm{A}$ （課題番号 16202022）研究成果報告書, $17-21$.

牛島千尋, 2001 東京圏における郊外人口の特徵と居住分化」曰日本都市社会学会年報』19, 23-38. 和田清美, 2006, 『大都市東京の社会学—コミュニティから全体構造へ一』有信堂高文社.

若林幹夫, 2000, 『都市の比較社会学』岩波書店.

一，2001，「郊外論の地平」『日本都市社会学会年報』19, 39-54.

一, 2007, 『郊外の社会学一現代を生きる形一』筑摩書房.

矢部直人, $2003,\ulcorner 1990$ 年代の東京都心における人口回帰現象『人文地理』55-3，79-94.

山田浩久, 2007, 「大都市圏域の地価変動現象に見られる土地評価の推移」藤井正『社会経済構造 の転換と 21 世紀の都市圏ビジョン一欧米のコンパクト・シティ政策と日本の都市圈構造一』 平成 $16 \sim 18$ 年度科学研究費補助金基盤 $\mathrm{A}$ （課題番号 16202022）研究成果報告書， 50-55.

山田 誠, 1994, 「京阪神大都市圏における住民の学歴構成の変動」高橋伸夫・谷内達『日本の三 大都市圈』古今書院.

山神達也, 2003,「日本の大都市圈における人口増加の時空間構造」『地理学評論』76-4, 187-210.

Yamashita, H., Fujii, T. and Itoh, S., 2006, "The Development of Diverse Suburban Activity Centres in the Melbourne Metropolitan Area", Applied GIS 2(2), pp.9.1-9.25, DOI:10.2104/ag060009. 